\title{
HASHIMOTO'S DISEASE:
}

\section{A REVIEW}

\author{
By Douglas R. K. ReID, M.D., F.R.C.S.*
}

- If we summarise the present clinical findings, we had four patients, all beyond forty years of age, not living in a goitre district, and with a family history negative for goitre. . . . They had never been seriously ill, and were without any of the serious infectious diseases frequently followed by disease of the thyroid, especially strumitis. Lues and tuberculosis were excluded clinically. The thyroid enlargement was discovered incidentally in all cases.

'We found a not very rapid enlargement of the thyroid, with good general health. ... Both lobes were involved in all cases. . . . Severe symptoms of pressure such as dyspnoea and aphonia have never been present. . . . Not a trace of inflammation of the thyroid could be found. The mass was freely movable, but the consistency was usually so firm that one would think of malignancy or Riedel's strumitis. There was neither regional nor general lymphadenopathy. No other visceral abnormality was found.

'The operative findings did not demonstrate much adherence to adjacent structures, as in cases of Riedel's thyroiditis. . . . Post-operative hoarseness was present in all cases, though slight in amount. In the post-operative course, an oedema of the entire body is said to have occurred, disappearing after the internal administration of thyroid. ...

'The chief findings in all cases were:

(i) Formation of numerous lymph follicles.

(ii) Striking changes in the epithelial tissue of the acini (atrophy) of the thyroid and their contents (absence of colloid).

(iii) Extensive proliferation of connective tissue and diffuse round-cell infiltration (lymphocytes and plasma cells).'-

Hashimoto, 1912, quoted by Lee and McGrath, 1937.

The disease described by Hashimoto in these terms nearly 40 years ago has ever since been attended by confusion and controversy. Its very existence as a clinical and pathological entity has been alternately affirmed and denied. It has been related to thyrotoxicosis on the one hand, and to myxoedema on the other. It is not fatal, yet com-

* From the Department of Surgery, Postgraduate Medical School of London, Hammersmith Hospital. paratively little is known of its course when untreated. Its diagnosis rests on histological findings, yet no one of these is pathognomonic, and the ultimate criterion is not the quality of the changes involved but their extent and quantity. It has been given at least three names and a score of aetiologies, and none has yet been found satisfactory. And though our knowledge of normal and disordered thyroid function has advanced so dramatically in the last decade, still no clear light has been shed on the pathogenesis of Hashimoto's disease. It appears to have no analogue in any other organ or disease process, yet neither has it been integrated with the peculiar physiology and pathology of the thyroid.

No further definition of the disease, other than the quotation above, will be offered at present; yet we must not too readily assume that Hashimoto's description, based as it was on only four cases, is necessarily final and completely comprehensive. The purpose of this paper is to examine the literature and to attempt to indicate what in retrospect seems paradoxical, and what in prospect may prove significant and of value in our future understanding of the disease. Further definition must await further elucidation.

\section{Incidence}

Most cases of Hashimoto's disease have been reported from Britain, the United States and Japan. It occurs on the Continent, but according to Joll (1939) is relatively rare in the endemic goitre areas of the Tyrol and Switzerland; my own small personal experience would suggest that it is similarly uncommon in New Zealand.

It is by no means a common condition, and has been variously reported from British and American sources as constituting from 0.17 to 1.7 per cent. of all thyroid glands removed at operation (Table 1 ). Graham in 1931 reviewed 104 cases of thyroiditis, and could find only 24 which, in his opinion, conformed to Hashimoto's description. McClintock and Wright (1.937) accepted 50 cases, and McSwain and Moore (1943) 71 cases, while in 1948 Goldberg and Davson referred to over 200 case reports in the literature. The largest individual series has appeared since then, and included 78 cases from 25,000 thyroidectomies, an incidence of $0.3 \mathrm{I}$ per cent. (Marshall et al., 1948). 
TABLE I

Showing the Incidence of Hashimoto's Disease Relative to the Number of Thyroid Glands Removed

\begin{tabular}{|c|c|c|c|c|c|c|c|}
\hline Author & & & & Year & $\begin{array}{l}\text { Number of } \\
\text { thyroidectomies }\end{array}$ & $\begin{array}{l}\text { Number of cases of } \\
\text { Hashimoto's disease }\end{array}$ & Incidence \\
\hline $\begin{array}{l}\text { Lee (U.S.) } \\
\text { Renton } \text { et al. (G.B.) } \\
\text { Joll (G.B.) }\end{array}$ & $\begin{array}{l}\cdots \\
\cdots \\
\cdots \\
\cdots \\
\cdots \\
\cdots \\
\cdots \\
\cdots \\
\cdots \\
\cdots\end{array}$ & $\begin{array}{l}\cdots \\
\cdots \\
\cdots \\
\cdots \\
\cdots \\
\cdots \\
\cdots \\
\cdots \\
\cdots \\
\cdots\end{array}$ & $\begin{array}{l}\cdots \\
\cdots \\
\cdots \\
\cdots \\
\cdots \\
\cdots \\
\cdots \\
\cdots \\
\cdots \\
\cdots\end{array}$ & $\begin{array}{l}1935 \\
1938 \\
1939 \\
1939 \\
1939 \\
1943 \\
1946 \\
1948 \\
1948 \\
1949\end{array}$ & $\begin{array}{r}1,800 \\
418 \\
5,650 \\
670 \\
1,600 \\
1,999 \\
1,938 \\
25,000 \\
900 \\
1,595\end{array}$ & $\begin{array}{r}3 \\
7 \\
51 \\
6 \\
25 \\
15 \\
9 \\
78 \\
3 \\
9\end{array}$ & $\begin{array}{l}0.17 \% \\
1.7 \% \\
0.9 \% \\
0.9 \% \\
1.56 \% \\
0.75 \% \\
0.4 \% \\
0.31 \% \\
0.33 \% \\
0.49 \%\end{array}$ \\
\hline
\end{tabular}

Of the 28 cases which Davison and Letton (1949) observed between 1935 and I949, no fewer than 26 . had occurred within the last six years of that period.

It would be unwise to assume that Hashimoto's disease is becoming any commoner, but Table 2 shows a peculiar alteration in the numbers of cases reported, relative to those of Riedel's thyroiditis. Up to the early 'thirties Riedel's disease was more common than Hashimoto's, the ratio being 2: I (Graham, I93 I), or 3: I (Lee, 1935). By 1937 the ratio was nearly I : I (McClintock and Wright), and in Joll's series (1939) it was completely reversed and was now $I: 8$. Paterson and Starkey ( 1948 ) reported a ratio of $\mathrm{I}: \mathrm{I}$, as did, roughly. Lasser and Grayzel (1949), but in Marshall's large series it was I : II. It is true that Marshall applied the term 'struma lymphomatosa' to mild, moderate and marked instances of diffuse lymphoid infiltration, but limited the use of Riedel's eponym to the cases of marked fibrosis. Comparing only the fully developed cases in this series, the ratio becomes $1: 4$ in favour of Hashimoto's disease.

The variability of the ratio and its apparent complete reversal in the course of 20 years may be accounted for in several ways: (a) It may be statistical error, due to the small numbers involved.

(b) It may be due to an actual fall in the incidence of Riedel's disease.

(c) It may reflect difficulty, and perhaps changing opinions, in the pathological classification of cases of thyroiditis. In this connection, it must be emphasized that the authors whose figures are quoted are those who have most sharply distinguished Hashimoto's from Riedel's disease, and at least to that extent have shared similar criteria-

(d) The alteration in the ratio has coincided with the perfecting, and consequent popularity, of the operation of thyroidectomy; it is feasible that, since fewer patients nowadays are content to exist goitrous for long: treatment of the earlier stage of a disease process has reduced the incidence of its later stage.

Considerations of age and sex incidence have played a large part in the distinction between Hashimoto's and Riedel's diseases. It is generally agreed that both are more common in females than in males; this seems to be particularly true of Hashimoto's disease and, according to Davison and Letton (1949), only eight male cases had been reported at that time.

Age incidences yield more room for criticism

TABle 2

Szowing the Incidence of Hashimoto's Disease Relative to that of Riedel's and other forms of 'Thyroiditis

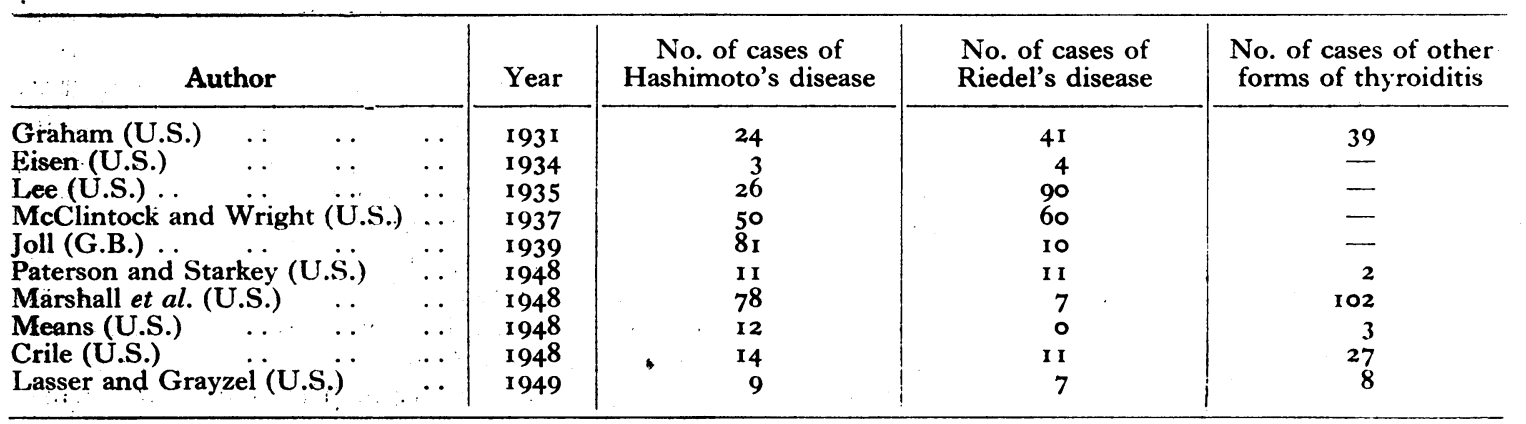


TABLE 3

Showing the Average Age Incidence of Cases of Hashimoto's and Riedel's Diseases in Various Series

\begin{tabular}{|c|c|c|c|c|c|c|c|c|}
\hline \multirow{2}{*}{\multicolumn{4}{|c|}{ Author }} & \multirow{2}{*}{$\begin{array}{l}\text { Year } \\
\text { r93I }\end{array}$} & \multicolumn{2}{|c|}{ Hashimoto's disease } & \multicolumn{2}{|c|}{ Riedel's disease } \\
\hline & & & & & Number & $\begin{array}{c}\text { Average age } \\
\text { (years) }\end{array}$ & Number & $\begin{array}{c}\text { Average age } \\
\text { (years) }\end{array}$ \\
\hline 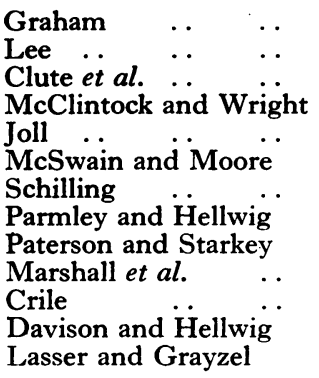 & $\begin{array}{l}\cdots \\
\cdots \\
\cdots \\
\cdots \\
\cdots \\
\cdots \\
\cdots \\
\cdots \\
\cdots \\
\cdots\end{array}$ & $\begin{array}{l}\ldots \\
\because \\
\cdots \\
\cdots \\
\cdots \\
\cdots \\
\cdots \\
\cdots \\
\cdots \\
\cdots\end{array}$ & $\begin{array}{l}\ldots \\
\cdots \\
\cdots \\
\cdots \\
\cdots \\
\cdots \\
\cdots \\
\cdots \\
\cdots \\
\cdots \\
\cdots\end{array}$ & $\begin{array}{l}1931 \\
1935 \\
1935 \\
1937 \\
1939 \\
1943 \\
1945 \\
1946 \\
1948 \\
1948 \\
1948 \\
1949 \\
1949\end{array}$ & $\begin{array}{r}24 \\
26 \\
9 \\
50 \\
81 \\
71 \\
5 \\
14 \\
11 \\
78 \\
14 \\
28 \\
9\end{array}$ & $\begin{array}{l}52.4 \\
47.6 \\
55 \cdot 5 \\
49.2 \\
57.6 \\
47 \\
30.4 \\
44.7 \\
43.8 \\
50 \\
49 \\
37.7 \\
38\end{array}$ & $\begin{array}{l}41 \\
90 \\
60 \\
5 \\
= \\
\text { II } \\
7 \\
\text { II } \\
7\end{array}$ & $\begin{array}{l}36.2 \\
43.6 \\
40.3 \\
44.4 \\
= \\
\overline{-} \\
44.8 \\
46 \\
51 \\
\frac{46}{4}\end{array}$ \\
\hline
\end{tabular}

and speculation (see Table 3). Graham (1931) reported an average age incidence of 52.4 years for Hashimoto's disease and 36.2 years for Riedel's. Presenting similar figures, Joll argued that the two conditions could not therefore represent stages of a single process. If later figures show anything, however, it is that the average ages for the two conditions have tended to approximate, until there is little apparent difference. It is doubtful whether, in fact, these average-age figures are of much value, either in describing the diseases or in distinguishing between them, as the range covered is so great. It is certainly true that most cases of Hashimoto's disease occur after the age of forty, but, as Table 4 shows, it is not rare in younger people. Many of the recorded cases have been below the age of thirty, and examples below twenty have been reported by Bogart (1928), Joll (1939), Schilling (1945), Parmley and Hellwig (1946), Means (1948) and Davison and Letton (1949). The youngest case on record seems to be a six-year-old female reported by Lasser and Grayzel (1949).

Joll (I939) stated that Riedel's disease occurred mostly below the age of forty, but Crile (1948) has recently stated that it is found most typically after the age of fifty. And, on the other hand, Merrington (1948) has pointed out that Schilling (1945) described Hashimoto's disease as occurring between the ages of forty and sixty, and yet in the same paper reported six cases, of which the ages of five are given as respectively seventeen, twentyseven, twenty-eight, thirty and fifty-two years. It is clear that a consideration of the literature hardly bears out the contention of Graham (I93I) and Joll (1939) that the age factor in itself forms a firm dividing line between the Hashimoto and Riedel types of thyroiditis.

\section{Clinical Features}

The most common symptom is the development of a goitre. Its average weight, according to

TABLE 4

Showing the Age Distribution of Hashimoto's Disease

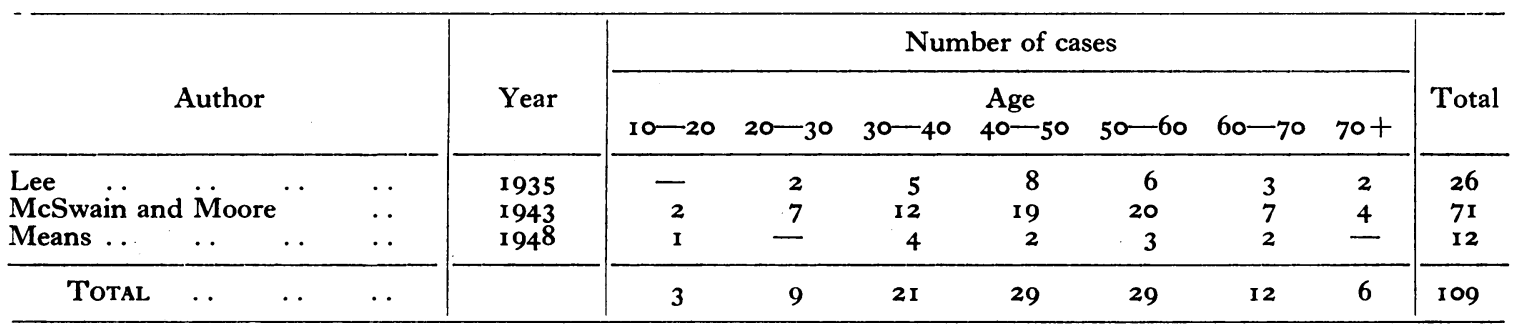

Showing the Age Distribution of Riedel's Disease (Lee's Series, i 935)

$$
\begin{aligned}
& \text { Age } \\
& \text { Number of cases } \\
& 10-20 \quad 20-30 \quad 30-40 \\
& 40-50 \\
& 50-60 \\
& 60-7070+ \\
& \begin{array}{llll}
28 & 14 & 8 & 1
\end{array}
\end{aligned}
$$


McSwain and Moore (1943), is 91 gm., and, according to Marshall (1948), I00 gm. Jaffe (1937) states that he has frequently found at autopsy glands of normal size or less which displayed the histological characteristics of Hashimoto's disease.

The goitre may grow slowly, or it may apparently attain its maximum size within a year; its average duration, according to Joll, is 4.2 years. There is rarely evidence of previous thyroid enlargement and, untreated, the condition shows no tendency to regress, as Crile (1948) has noted in a patient whose goitre was present for eight years before operation.

Symptoms referable to the goitre may or may not be present. Their average duration is given by McClintock and Wright (1937) as 1.3 years and by Marshall (1948) as 26 months. Pain and tenderness are generally reported to be uncommon, but are noted by Paterson and Starkey (1948) in 5 out of their I I cases and by Crile (1948) in 3 out of 14 cases. Pressure symptoms are on the whole slight, and seem to be proportionate to the size of the goitre. $\mathrm{X}$-rays of the trachea frequently show deviation, lateral or antero-posterior compression, or a forward displacement which is due to encirclement of the trachea by the thyroid lobes.

Typically, the goitre is a diffuse enlargement, involving both lateral lobes, isthmus and pyramidal lobe. The right lobe is often the larger, and this is said by Joll to reflect the normal asymmetry of the gland. Unilateral cases have occurred (Means, 1948) and, in others, although the histological changes are uniform throughout both lobes, one of these may be disproportionately large. I have recently, for example, removed a gland of which one lobe (the right) weighed $180 \mathrm{gm}$. and the other only $40 \mathrm{gm}$.

The goitre is of firm, rubbery consistence, and its surface is smooth, lobular rather than nodular. It is usually mobile, and apparently free of adhesions to the overlying muscles. The cervical lymph-nodes are not, as a rule, palpable, although the so-called 'Delphian' node (Cope, I948), which lies above the isthmus, is often observed at operation.

Usually the onset of Hashimoto's disease is insidious, but fever and leucocytosis have been observed (Means, I948). Pedigo and Abramson (1947) describe a case in which the onset was sudden and was accompanied by fever, painful joint swellings and evidence of thyrotoxicosis; the histological sections were passed by Foot as being characteristic of Hashimoto's disease.

The patient may be euthyroid when first seen, or hypothyroid as was the case in 8 per cent. of Marshall's series (1948), but many authors claim to have observed an early hyperthyroid phase.
Thus Davison and Letton (1949) refer to emotional upset and nervousness; McSwain and Moore (1943) state that loss of weight is more common than gain initially; Parmley and Hellwig (1946) mention tachycardia, sweating and tremor in some cases, while Hori (1946) and Sinaiko et al. (1948) report mild exophthalmos in patients with Hashimoto's disease.

Marshall (1948) believes that alteration of the general health is not a prominent feature, unless hypothyroidism is present, and states that such symptoms as nervousness and fatigue are observed mostly in patients with 'a strong tendency to neurosis or a phobia of cancer.' Schilling (1945) considered that mild cervical pressure, rather than thyrotoxicosis, was the cause of nervousness, vertigo, tremor and insomnia. The association of frank clinical thyrotoxicosis with the histological features of Hashimoto's disease has, however, been reported by several authors, including Polowe (1934) and Eden and Trotter (1942); further, basal metabolic rates have been recorded up to +57 per cent. (Goldberg and Davson, 1948), +63 per cent. (McSwain and Moore, 1943) and +69 per cent. (Pedigo and Abramson, 1947).

Joll accepted the existence of a hyperthyroid phase as an accompanying and perhaps incidental feature of the early stage in some cases, but he denied the theory which had been propounded by Eason (1928) and supported by Vaux (1938), that Hashimoto's disease was the end-result of a burntout thyrotoxicosis. It is clear that there is a serious lack of clinical agreement as regards the association of toxic features with Hashimoto's disease, but there is no doubt that its course is towards progressive hypothyroidism in almost every case. Operation merely serves to hasten its onset, and Marshall found that 75 per cent. of his cases showed post-operative hypothyroidism. Generally this may be controlled by thyroid medication, but some cases, according to Crile (1948), do not respond satisfactorily. He prefers the term 'hypometabolism' to describe their condition, and emphasizes systemic features such as anaemia, achlorhydria and a lack of well-being, which may last for years after operation, in spite of thyroid administration.

Recurrence of lymphadenoid goitre after operation does not seem to occur, except where the original operation has been a unilateral lobectomy and 'recurrence' takes place in the remaining lobe.

By contrast, the clinical features of Riedel's thyroiditis are listed by Joll (1939) as a relatively more rapid development of a smaller, and initially unilateral, goitre, which produces marked pressure symptoms in a large proportion of patients, and which is not associated with pre-operative 

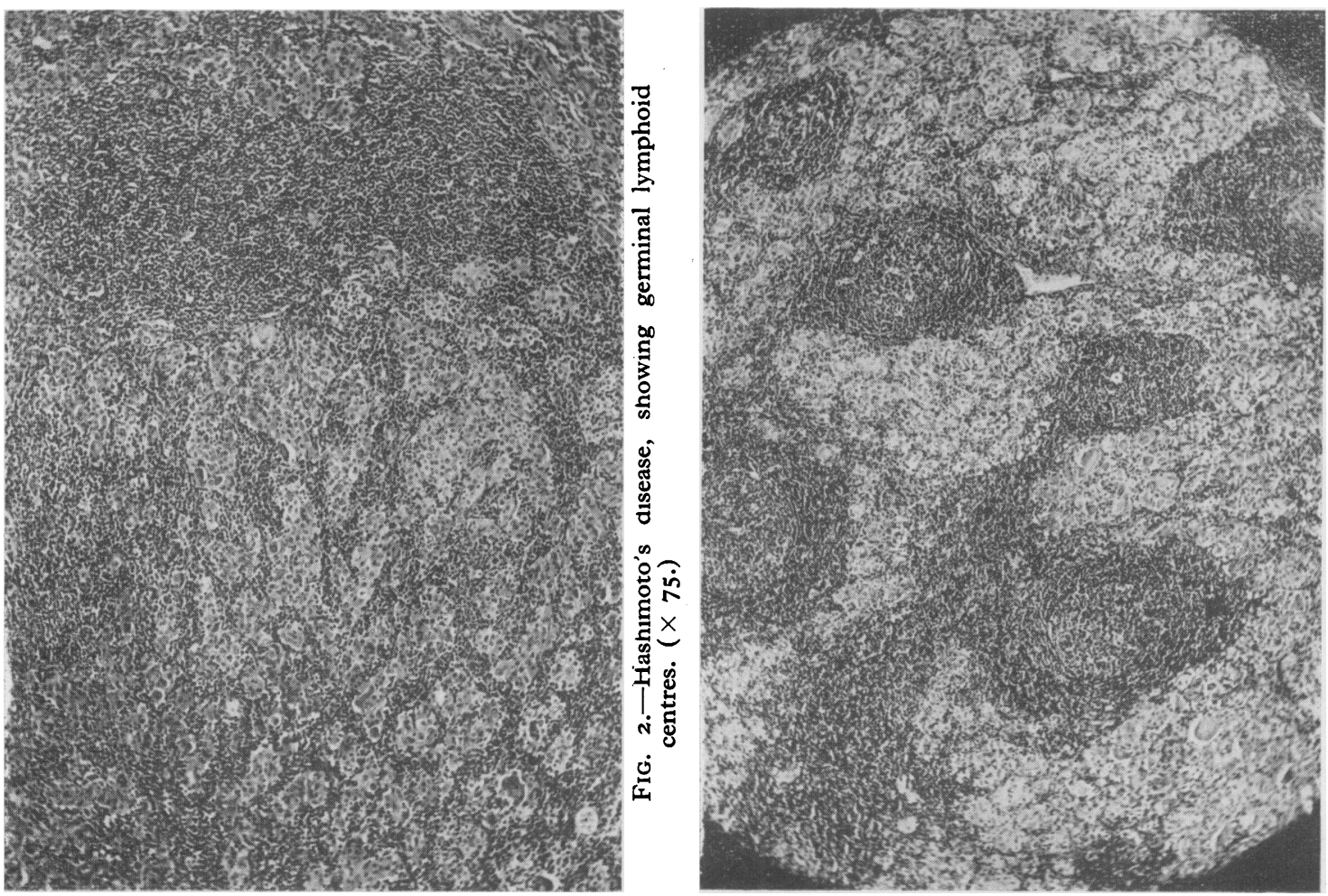

음

密

호

흥 흠

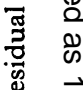

$\overrightarrow{0}$

욤

\%

․ㅗ․ㅡ.

\&

虫

क क

$\stackrel{\circ}{\infty}$

g्コ

웡

出

;

نे

무.

흘일

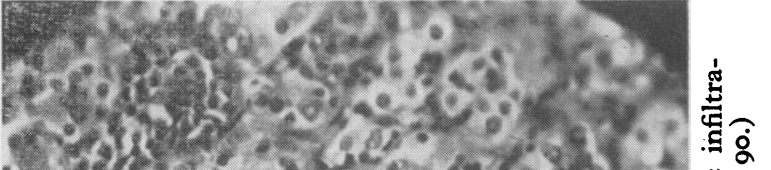

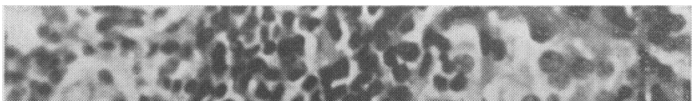
i.

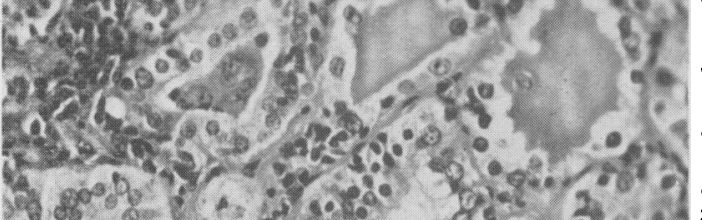

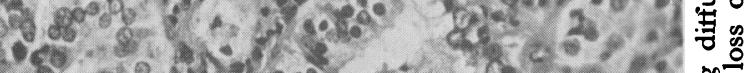

04 d

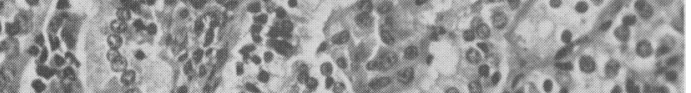

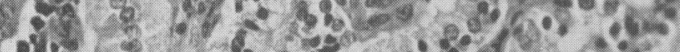

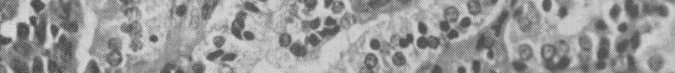

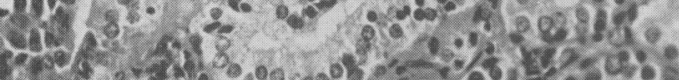

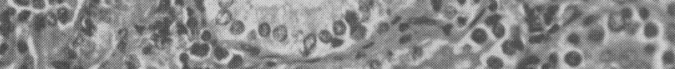
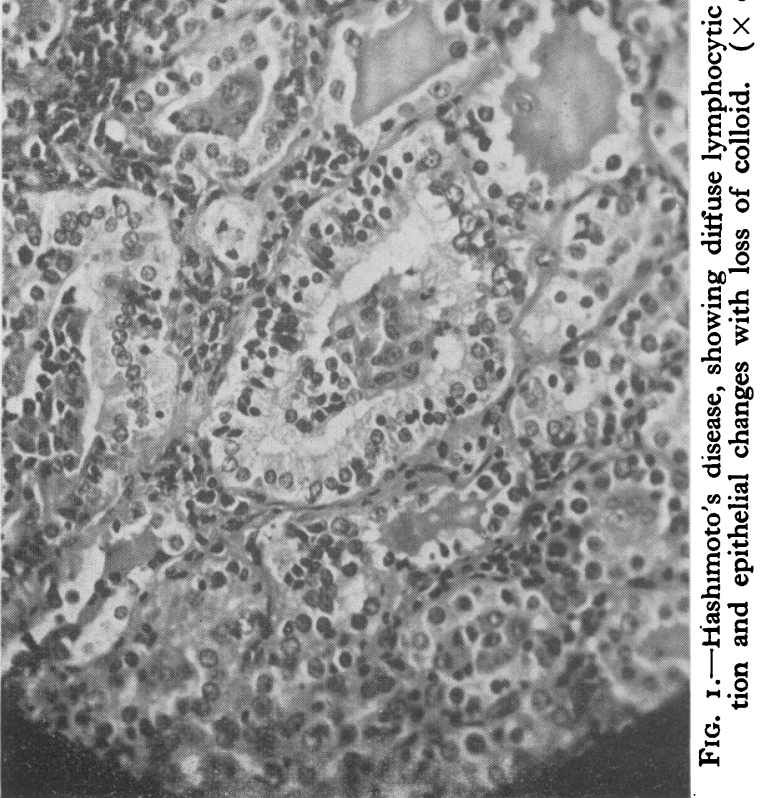

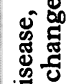

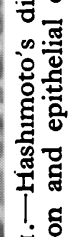

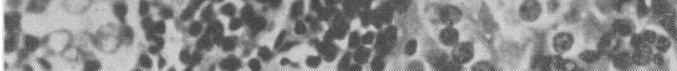

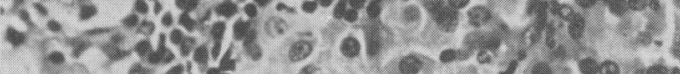

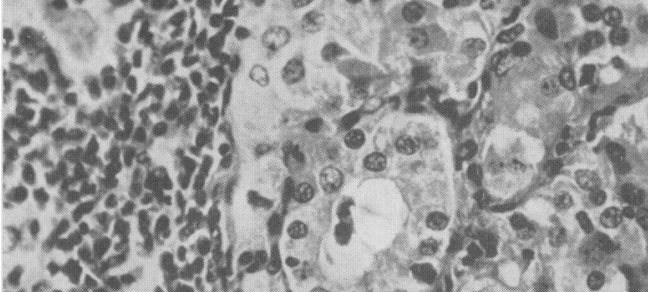

:

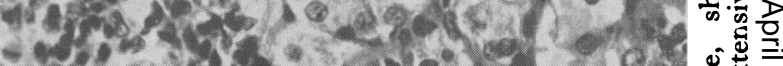

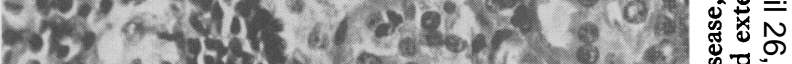

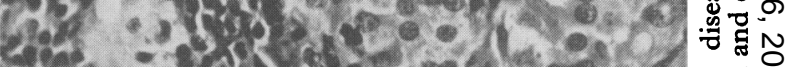
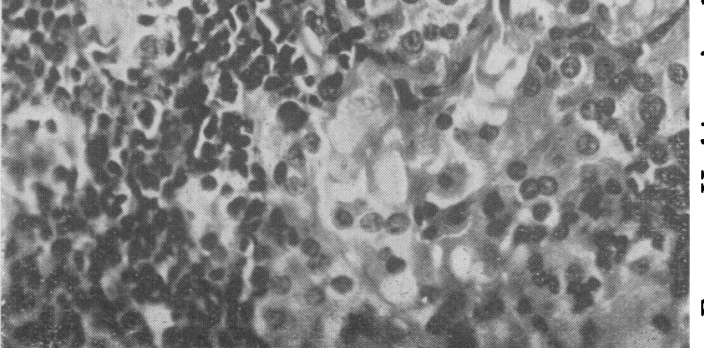

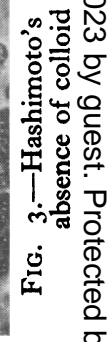


hypothyroidism so often as is Hashimoto's disease. It is doubtful, however, whether many of these differential points are entirely valid. Thus, judging from Marshall's figures, there appears to be little difference between the duration of the two conditions, and Crile (1948) has specifically described the goitre in Riedel's disease as a 'bulky' tumour. Further, while Marshall found 8 per cent. of his cases of ' struma lymphomatosa' hypothyroid before operation and 75 per cent. afterwards, his corresponding figures for fibrous thyroiditis were 7 per cent. and 27 per cent. In the histologically advanced cases, post-operative hypothyroidism was observed in respectively 93 per cent. and 57 per cent. of the lymphoid and fibrous types. The difference before operation at least is not appreciable. It is clear, although it is not surprising, that the fibrosing condition described by Riedel does produce more striking pressure effects than does lymphadenoid goitre, but as Merrington (1948) has stated, '. . . there is a single broad clinical picture common to both (diseases), and attempts to draw a line between them have not been convincing.'

\section{Pathology}

It may ill become one who is not specially trained in pathology to discuss the morbid changes in a subject so complex and so difficult of interpretation as Hashimoto's disease. A general discussion based on the literature may not, however, be considered presumptuous.

The lymphadenoid goitre is commonly of moderate size; the enlargement may be diffuse, asymmetrical or infrequently unilateral. Its surface is lobulated and its consistency firm. When cut, the tissue has been described in terms ranging from friable to tough, and its vascularity is as a rule reduced. In colour it is white, grey, pink or ' lavender yellow' (Davison and Letton, I949). The cut surface is homogeneous; colloid is absent or scanty, and there is a noticeable absence of necrosis, haemorrhage or calcification. The capsule may be moderately thickened.

Graham (I93I) and Joll (1939) have regarded the absence, in Hashimoto's disease, of extraglandular infiltration and adhesions to surrounding structures as a cardinal point in its differentiation from Riedel's thyroiditis. Eisen (1934) has, however, criticized Graham's paper on the score that he failed to mention such changes in cases where the original authors (e.g. Shaw and Smith, 1925) specifically described them. The same criticism must be made of Joll's reference to Renton, Charteris and Heggie's paper (1938); he regarded their cases as examples of Hashimoto's disease, but ignored the fact that they described and illustrated lymphoid and fibrous infiltration of the sternothyroid and sternomastoid muscles in their first case. Taylor (I95I) has recently seen a case of this type, in which extensive infiltration of muscles by the lymphadenoid process has been demonstrated histologically.

Eisen's own cases showed 'definite extracapsular adhesions,' as also did those reported by Oldfield (1948) and Merrington (1948). Hori (1946) stated that in all of his cases-two of Riedel's and three of Hashimoto's disease----the gland was adherent to the trachea and difficult to remove. Indeed, Sinaiko (I948) found in one case that the thyroid was 'so extremely adherent to the trachea, that no plane of dissection could be found.' These cases are, no doubt, isolated instances, but they seem to occur sufficiently frequently to warrant consideration, and perhaps to cast a shadow of doubt on yet another of the accepted criteria of distinction between Hashimoto's and Riedel's diseases.

\section{Histology}

The histological picture comprises diffuse lymphocytic infiltration, more or less numerous lymph follicles, minimal fibrosis and certain epithelial changes.

Throughout the gland an abundance of lympho- 0 cytes infiltrates the peri-acinar and peri-lobular tissues; focal lymphoid aggregates form both pseudo-follicles and true germinal centres, which contain reticulo-endothelial cells, plasma cells and lymphocytes. Monocytes are found in small numbers, but polymorphs are usually absent. Foreign-body giant cells are present, and also 'false' giant cells which appear to consist of acinar cells lying in colloid and to represent the remnants of a disintegrating acinus.

Fibrous tissue is present in variable amount; classically, it is minimal in amount, fine in texture, and arranged in whorls around lobules of thyroid tissue. Schilling (1945) admits that there may be complete fibrous replacement of the lobule, but does not accept any relationship with Riedel's disease.

Joll regarded these changes as being primary, and pathognomonic only if they were diffuse, uniform, and included true germinal centres. It seems desirable at this point, however, to devote some consideration to histologically similar changes of a localized nature. Simmonds, in 1913, found focal lymphoid changes in 5 per cent. of normal thyroids, in 15 per cent. of non-toxic goitres and in 75 per cent. of toxic goitres. In the last category, his figure was confirmed and indeed exceeded by Kocher, Wegelin and Hertz (1943). These changes were found predominantly in females, and only on subjects over the age of thirty. Graham (I93I) recognized these findings and 
stated, rather optimistically, ' . . . were it possible to assume an antecedent hyperthyroidism, an explanation of the pathogenesis of struma lymphomatosa would not be difficult.' Joll, on the other hand, admitted the existence of a hyperthyroid phase in some cases, but would not accept focal lymphoid changes as being of the same nature as Hashimoto's disease.

Hellwig (1938) found lymphoid foci in 23.3 per cent. of cases of exophthalmic goitre. Vaux (1938) and Goldberg and Davson (1948) have traced lymphoid changes along a scale ranging from hyperplastic goitre on the one hand, to Hashimoto's disease on the other, and believed that the degree of clinical toxicity was inversely proportional to the extent of lymphoid involvement. Recently Greene (1950) has distinguished between simple lymphocytic infiltration and ' lymphadenoid foci,' containing true germinal centres, and has found the latter in 44 out of 161 thyroids removed for toxic symptoms. These 44 cases were all females, ranging in age from eighteen to seventy-five. Two were examples of Hashimoto's disease, and out of 43 , no fewer than 20 developed 'frank and definite hypothyroidism ' post-operatively. By contrast, hypothyroidism did not develop in any one of those 117 cases in which no lymphadenoid foci were found. Greene believes that such foci are not merely histologically similar to Hashimoto's disease, but that in fact they constitute its earliest stage. Whitesell and Black (1949), at the Mayo Clinic, have studied 86 cases of exophthalmic goitre in which lymphocytic infiltration and fibrosis were present in the glands.

Their conclusions are :

(a) Lymphocytes and fibrous tissue are an integral part of the histological picture of exophthalmic goitre.

(b) Thyroid acini may be replaced by lymphocytes alone, or by both fibrous tissue and lymphocytes.

(c) Patients with the mixed fibro-lymphocytic changes were somewhat older than patients with lymphocytic type.

(d) Female patients showed greater replacement than male patients in each decade.

(e) With greater degrees of replacement the basal metabolic rates were lower, and the incidence of auricular fibrillation less.

(f) The incidence of exophthalmos increased progressively with increasing degrees of replacement.

(g) The incidence of post-operative myxoedema rose progressively with increasing degrees of replacement. In some cases showing 40 to 50 per cent. replacement, the incidence of post-operative myxoedema approached 70 per cent.
It is thus evident that a strong case can be made out for linking focal lymphadenoid changes in toxic goitres with Hashimoto's disease. In general terms, it might be said that these changes are, in some cases of hyperplastic goitre, the prelude to and the accompaniment of diminishing endocrine function.

The lymphadenoid features of Hashimoto's disease are so striking that they have tended to overshadow those changes in the acinar epithelium which Hashimoto himself recognized and described as degeneration and atrophy. Joll (1939) and Schilling (1945) have described these changes very fully. The acini are small and shrunken, colloid is scanty or absent, and there are occasional intra-acinar collections, apparently of desquamated epithelial cells or even lymphocytes admixed with residual colloid. According to Schilling, the picture is one of diffuse and uniform epithelial degeneration, but Joll recognized the occurrence of epithelial hyperplasia. In this he was in agreement with Shaw and Smith (1925), Williamson and Pearse (1928) and many other authors and, like them, believed that it was compensatory hyperplasia following strangulation and destruction of thyroid tissue. Renton et al. (1938) also described hyperplastic changes, but found them difficult to reconcile with clinical hypothyroidism.

An attempt to measure the relative quantity of lymphoid and epithelial tissue in lymphadenoid goitres has been made by Parmley and Hellwig (1946), and their results, if substantiated, are of the greatest possible significance. They found that only one-third of the total thyroid enlargement could be attributed to lymphoid tissue; the remaining two-thirds consisted of epithelial tissue, indicating a very considerable increase in its total amount.

Moreover, most authors have noted the extensive replacement of normal epithelial cells by large, pale, eosinophilic cells. These may occur singly, or more usually in small but complete acini which are devoid of colloid. In some cases the cells may be so packed together that they appear as solid areas, such as Renton et al. have described as 'syncytial hyperplasia.' Hellwig (1938) related the cells to a similar type seen in chronic mastitis, but Womach (r944) identified them with the socalled Hürthle type of cell, from which indeed they are indistinguishable. So characteristic are they of Hashimoto's disease, that Crile (1948) and Marshall (1948) regarded 'acidophilic degeneration' as an integral part of the histological picture.

Lennox (I948) has pointed out that this large, pale, eosinophilic cell should properly be named after Askanazy, who found it in toxic goitres in 1896; and, in a most valuable paper, Lennox has described the incidence of acini composed of such 
cells in various thyroid conditions. He found that these were:

(a) Rare in young subjects and in males of all ages.

(b) Fairly common in otherwise normal thyroids in elderly women.

(c) Present in 5 per cent. of non-toxic goitres.

(d) Present in I6.33 per cent. of cases of Graves' disease.

(e) Present in 50 per cent. of cases of toxic adenomata.

(f) Present in all six cases of lymphadenoid goitre studied.

(g) Absent in four cases of Riedel's thyroiditis.

(h) Present in the thyroids of myxoedematous subjects only when lymphoid tissue was present, and absent when the gland was predominantly a fibrous one.

It is of obvious interest that the Askanazy cell was present more often in toxic than in non-toxic goitres, and that it was constantly present in Hashimoto's disease, but of particular importance is the observation that it was almost always accompanied by and often imbedded in lymphoid tissue. This association was constant, except for some otherwise normal thyroids which contained lymphoid tissue but no Askanazy cells, and foetal adenomas which contained Askanazy cells but no lymphoid tissue. Lennox suggested that the Askanazy cell-lymphoid tissue complex represented a phase of regression, through which hyperplastic acini passed before finally disappearing. He adduced some evidence to show that the cell was of low endocrine function, and believed that, in his case of toxic adenoma, spontaneous cure of toxic symptoms occurred as a result of Askanazy cell replacement or metaplasia of the original cells.

Friedman (1949) describes the Askanazy cell as a large, pale, eosinophilic cell, with a hyperchromatic nucleus which is often bizarre in shape, and a well-defined cell membrane. He mentions granular and foamy types, and believes that he has observed its metaplasia from the normal cell type. He found it to have a distribution similar to that described by Lennox, and also noted its relationship to lymphoid tissue. In addition, however, Friedman found it in toxic goitres following both thiouracil and X-ray treatment, and in the thyroid remnants left after operation. In one most significant case, the progress of the histological picture from hyperplasia to Hashimoto's disease was observed over a period of eight years. According to Friedman, the Askanazy cell is the result of 'cellular involution' following prolonged hyperplasia.

Summing up, it appears to be now possible to state, with some degree of certitude, that:

(a) Replacement of normal thyroid cells by the
Askanazy type is constantly associated with lymphoid infiltration:

(b) These changes are found most frequently in toxic goitres on the one hand, and in Hashimoto's disease on the other.

(c) These changes are associated clinically with diminution of thyroid function.

(d) The thyroid in Hashimoto's disease is hyperplastic in the sense that the total amount of epithelial tissue is increased.

\section{Aetiology}

It is natural that many early writers, dealing with thyroiditis as a single subject, should have suggested an infective aetiology, and these views have been summarized by 'Lee (1935). Although no proof of infection was forthcoming, there were described several cases of thyroiditis, including the Hashimoto type, which appeared to follow various infections and toxaemias, and Ewing (1922) considered that both Hashimoto's and Riedel's diseases were but phases of the same granulomatous process. Graham's sharp separation of the two conditions discouraged further infective aetiologies for lymphadenoid goitre, although they continue to flourish as a widely accepted basis of Riedel's disease.

Iodine medication was incriminated by severato authors (Reist, I922; Boyden, Coller and Bugher 1935; and Dunhill, 1937), but there appears to be little support now for this theory: De Courcy (1942) believed that perithyroiditis and consequent ischaemia resulted in the fibrosis of Riedel's disease, but Goldberg and Davson (1948) also adduced ischaemia to account for the changes of Hashimoto's disease.

McCarrison (1928) was able to produce lymphadenoid changes in the thyroid glands of rats fed on a diet deficient in vitamins; his findings have received scant consideration from clinicians, who see no evidence of avitaminosis in their patients, but his experiments seem to be well worthy of repetition.

Many authors have taken the lymphoid changes of Hashimoto's disease to constitute the primary lesion; Hashimoto himself appears to have done so, and considered that some relationship might exist between struma lymphomatosa and Mikulicz's syndrome. Joll stated categorically that " the evidence is all in favour of the lymphoid changes being primary,' but had to admit that they appeared to be "neither inflammatory, neoplastic nor degenerative.'

Graham (I93I) thought that Hashimoto's disease was the local expression of a constitutional disorder, and Crile (1948) has recently emphasized the evidence for this view. Schilling (1945) believed that epithelial degeneration was the 
primary lesion and that lymphoid infiltration was a secondary replacement process, occurring in the burnt-out gland of an elderly woman. This view does not take into account, however, what Joll described as the intense intrinsic activity of the lymphoid tissue-an activity which seemed to him to transcend any mere process of replacement.

The existence of epithelial hyperplasia has already been emphasized; Williamson and Pearson (1929) ascribed the presence of many ' large eosinophilic cells' to proliferation of 'subnormal' thyroid epithelium, while Parmley and Hellwig (1946) attempted to explain it on the basis of disordered ovarian function, with not very convincing results.

Other authors, including Eason (1928), Polowe (1934), Vaux (1938) and Goldberg and Davson (I948), have accepted a phase of hyperthyroidism as a significant aetiological factor. and have in the main conceived Hashimoto's disease to be the result of exaggerated involutionary changes. To this view the histological observations of Lennox, Greene, Friedman, and Whitesell and Black have brought a large measure of support, although a phase of hyperthyroidism cannot be regarded as sufficiently common or sufficiently well established as to constitute a basis for all cases of Hashimoto's disease. Nevertheless, it seems now possible to define Hashimoto's disease as a series of changes which include extensive Askanazy cell metaplasia of the thyroid epithelium and lymphocytic infiltration of the inter-acina tissues, which occur in a hyperplastic gland and which are associated with diminishing endocrine function.

Such is our conception of the pathological mechanism: but before progress is made towards the synthesis of an aetiology, the following questions remain to be answered:

(a) What is the nature of the Askanazy cell ?

(b) What is the nature of its relationship to lymphoid tissue?

(c) Is a phase of epithelial hyperplasia a necessary factor in the development of the disease ?

(d) Can such hyperplasia exist in the absence of clinical hyperthyroidism ?

(e) Would all thyroids which are the seat of epithelial hyperplasia ultimately show Askanazy cell change and lymphoid infiltration?

(f) Can such changes arise in a previously normal thyroid ?

Firm answers exist to few, if any, of these questions. The nature of the Askanazy cell, for example, remains in doubt. Williamson and Pearse (1929) and Parmley and Hellwig (1946) believed that the 'large eosinophilic cell' was a young, proliferative and regenerative type, but
Lennox (1948) and Friedman (1949) describe it respectively as regressive and involutional.

Friedman has made a distinction between follicular. involution, comprising colloid storage in large acini lined by flat cuboidal epithelium, and cellular involution, consisting of Askanazy cell degeneration with its accompanying lymphoid changes. $\mathrm{He}$ believes that cellular involution is one possible end-result of prolonged hyperplasia and states: 'Such morphologically demonstrable hyperplasia is not necessarily associated with hyperfunction in the sense of secretion.' In support of this statement, he cites the proliferative but functionally ineffective goitre which results from either iodine deficiency or thiouracil medication, and there is no reason to believe that these necessarily exhaust all the possible factors which might lead to hyperplasia without hyperfunction.

It is Friedman's view that Hashimoto's disease is the end-result of prolonged hyperplasia and cellular involution. His work suggests that the contlition may be a mode of thyroid failure, in which a tendency to diminishing function is at first off-set by epithelial hyerplasia, with occasional slight evidences of hyperthyroidism, but, incapable of sustaining even a moderately high level of functional activity, the epithelium passes into a state of cellular involution. Further diminution in endocrine function may then result, followed by the same vicious cycle of hyperplasia, involution and hypofunction in such acini as are still normal, until the gland is diffusely involved and the patient is clinically deficient in thyroid secretion.

This hypothesis is largely speculative, but it possesses certain merits; for example, it might account on the one hand for the development of lymphadenoid changes in toxic goitre, and on the other hand for the development of Hashimoto's disease in a previously normal gland. It might also explain the existence, in Hashimoto's disease, of epithelial hyperplasia and endocrine hypofunction, with, in some cases, fleeting evidences of thyrotoxicosis in the early stages. There exist, of course, certain serious objections to this view. Hashimoto's disease is reputedly uncommon in those goitre areas where prolonged epithelial hyperplasia is common and where involution is usually of the follicular type. Further, extensive Askanazy cell change and lymphoid infiltration have not been described as resulting from prolonged thiouracil therapy. Were it possible to assume in some individuals, as Williamson and Pearse have done, a thyroid cell of intrinsically low potential, by reason of constitutional or extrinsic factors as yet unknown, and that this cell were incapable of responding in a functionally effective manner to even physiological demands, then the 
epithelial changes of Hashimoto's disease might be easier to understand.

The mechanism of lymphoid infiltration remains obscure. Jaffe (1937) believed that it was due to excessive resorption of secretory products from disintegrating thyroid acini, but when Ferguson (1933) injected human colloid into the thyroids of guinea-pigs, he found that the histological reaction was merely the non-specific one of fibrosis with foreign-body giant cells. Although applicable in part to Hashimoto's disease, these findings would hardly appear to account for all the lymphoid changes involved. It is interesting to note in passing that Sheehan and Summers (1949) have described (after Simmonds) a ' granulomatous have described (after Simmonds) a ' granulomatous' condition of the pituitary, which they liken to 'pseudo-granulomatous nodules in (some) atrophying thyroids.' The condition they describe consists of endocrine failure, slight enlargement, epithelial atrophy and lymphocytic infiltration of the pituitary, with the appearance of giant cells, which they consider may represent groups of disintegrating epithelial cells.

Shaw and Smith (1925) noted lymphocytic infiltration of the adrenals in a case of Hashimoto's disease, and similar changes are present in the adrenals in 20 per cent. of those cases of Addison's disease which are due to primary cortical atrophy (Vines, 1940). It is generally accepted that thyroid and adrenal function are to some extent interdependent and, further, that there is a relationship between adrenal activity and the behaviour of lymphoid tissue. It is conceivable that the prolonged ill-health and 'hypometabolism,' which Crile (1948) has emphasized in connection with Hashimoto's disease, may in time be related to some form of adrenal failure or dysfunction, although at the present time no evidence seems to exist for this view.

One further consideration remains, merely to be introduced tentatively into this discussion. It is reported (Rawson et al., 194I) that, apart from thyroid epithelium, lymphoid tissue alone possesses any significant ability to inactivate the thyroidstimulating hormone of the pituitary. It is tempting to think that this observation may bear some relationship to lymphadenoid change, but there are at present no grounds for doing so.

\section{Treatment}

Hashimoto's disease is not always clinically diagnosed as such and, in the absence of definite hypothyroidism, may be difficult to distinguish from nodular goitre and from carcinoma of the thyroid. The usual treatment, therefore, is subtotal thyroidectomy, and this has the merit of removing an unsightly swelling, eliminating or preventing pressure symptoms and of affording an opportunity for histological diagnosis. Postoperative hypothyroidism is usual and may be controlled by thyroid medication.

Radiotherapy has been favourably mentioned by Renton, Charteris and Heggie (1938), Schilling (1945), Means (1948) and Crile (1948). McSwain and Moore (1943) suggested that hypothyroidism was possibly less common after radiation than after operation, but there seems to be little evidence for this view. Indeed, radiation has not been employed by Marshall et al. (1948), lest it should damage any remaining functioning tissue. There would appear to be little advantage in radiotherapy, and it should certainly not be employed without biopsy to exclude carcinoma.

In view of the existence of epithelial hyperplasia in Hashimoto's disease, it seems reasonable to suggest treatment by thyroid alone; its effect might include not only relief of the symptoms of hypothyroidism, but conceivably also protection of the epithelium against further hyperplastic changes, and even its return to a normal resting state. I can, however, find no record of a case treated in this way. Thyroid therapy is, of course, almost invariably used after operation, and it is an interesting speculation that this may account for the rarity of post-operative recurrence of the goitre.

\section{Hashimoto's and Riedel's Diseases}

A strong body of literature has grown up (Graham and McCullagh, I93I ; McClintock and Wright, 1937; Joll, 1939; McSwain and Moor, 1943; and Schilling, I945) in support of Hashimoto's original contention that the two conditions are separate entities, and this is the opinion generally held today (Aird, 1950). The opposing view, that they are in some way related, has been expressed by Ewing (1922), Eisen (1934), Poer, Davidson and Bishop (1936), Vaux (1938) and Merrington (1948). Generally, these authors have believed Riedel's to be a late stage of Hashimoto's disease, and it was this theory in particular that was attacked by Joll.

Earlier in this paper, under the headings of incidence, clinical features and pathology, it has been suggested that some of Joll's differential points were perhaps of doubtful validity. It remains true that Riedel's disease is more frequently unilateral, at least to begin with, and occurs more often in males than does Hashimoto's disease. But the only fundamental distinguishing feature seems to be the predominance of lymphoid tissue in the one condition and of fibrous tissue in the other, and the transition from cellular infiltration to fibrosis is perhaps the commonest sequence of events in pathology. It is true, how- 
ever, that the transition from Hashimoto's disease to Riedel's has not been observed with certainty, although Heyd (1929) believed that he had done so. Perman and Wahlgren (1927), Roulet (1931), McClintock and Wright (1937), Hellwig (1938) and Schilling (1945) have all obtained thyroid tissue from cases of Hashimoto's disease at intervals ranging from 18 months to 9 years, and in no case found evidence of a histological change in the direction of Riedel's disease.

On the other hand, there have been reported cases which seem to lie somewhere between Hashimoto's and Riedel's diseases, possessing some of the characteristics of each. Such intermediate types have been recorded by Schilling (1945), Means (1948), Merrington (1948) and Oldfield (1948). It appears that there is, in Merrington's words, 'convincing evidence that the two conditions known as Hashimoto's and Riedel's thyroiditis can be present in the same gland at the same time.'

There may be merit in Womach's suggestion (1944)' that the two conditions are but varying manifestations of the same disease process, but the problem remains unsolved, as it must remain until more facts are available. It seems likely, however, that the apparently decreasing incidence of Riedel's disease will render its differentiation of less moment, and that future controversy will centre rather on the aetiological aspects of lymphadenoid goitre.

\section{Summary}

Hashimoto's disease is described and the literature is reviewed. It is concluded that the cardinal features of the condition are epithelial hyperplasia, extensive Askanazy cell change and lymphoid infiltration, in association with diminished thyroid function. The possible significance of these findings is discussed.

\section{Acknowledgments}

It is a pleasure to record my indebtedness to Dr. I. Doniach and Dr. Russell Fraser for their advice in the preparation of this paper, and to Mr. K. G. Moreman, A.R.P.S., for the photomicrographs.

\section{BIBLIOGRAPHY}

ASKANAZY, M. (1898), Deutsch. Arch. f. Klin. Med., 61, 118. BOGART, c uoted by SCHILLING; discussion, LEHMAN, J. A. Third Int. Goitre Conference, Amer. Ass. Study Goitre, 1928.

BOYDEN, A. M., COLLER, F. A., and BUGHER, J, C. (1935),

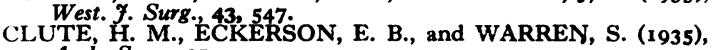
Arch. Surg., 31, 419.

COPE, O. (1948), MEANS, 'The Thyroid and its Diseases,' 2nd Ed.

CRILE, G. (1948), Arch. Surg., 57, 443.

CRILE, G. (1948), Ann. Surg., 127, 640

DAVISON, T. C., and LETTON, A. H. (1949), f. Clin. Endocrin., $9,980$.

DE CỎURCY, J. L. (1942), Surgery, 12, 754.

DUNHILL, SIR THOMAS (I937), Trans. Med. Soc. Lond., 60, 2462.

EASON, J. (1928), Tr. Med.-Chir. Soc. Edin., 42, 169.

EDEN, K. C., and TROTTER, W. R. (1942), Brit. F. Surg., 29, 320.

EISEN, D. (1934), Canad. Med. Ass. F., 21, 144. W. B. Saunders.

FERGUSON, J. A. (1'933), Arch. Path., 15, 244.

FICARRA, B. J. (1946), Arch. Surg., $52,729$.

FRIEDMAN, N. B. (1949), Ұ. Clin." Endocr., $9,874$.

GOLDBERG, H. M., and DAVSON, J. (1948), Brit. J. Surg., 36,

GRAHAM, A. (1931), West. F. Surg., 39, 68r.

GRAHAM, A., and McCULLAGH, E. P.' (1931), Arch. Surg., 22,548 .

GRAHAM, J. (1939), guoted by JOLL.

GREENE, R. (1950), $\mathcal{F}$. Endocrin., 7, 1 :

HASHIMOTO, H. (1912), Arch. f. Klin. Chir., 97, 219.

HELLWIG, C. A. (1938), Arch. Path., 25, 838.

HERTZ, J.' (1943), 'On Goitre and Allied Diseases,' Oxford University Press.

HEYD, C. G. (1929), Surg. Clin. N. Amer., 9, 493.

HORI, C. G. (1946), Canad. Med. Ass. F., 55, 372.

JAFFE, R. H. (1937), ₹.A.M.A., 108, 105.

JOLL, C. A. (1939), Brit. F. Surg., $27,351$.

KEYNES, G. (1939), quoted by JöLl.

KOCHER, quoted by HERTZ, 1943 .

LEE, J. G. (1935), Arch. Surg., 31, 982.

LEE, J. G. (1935), Arch. Surg., 31, 982.

LENNOX, B. (1948), F. Path. Bact., \$0, 295.

LUNDBAEK, K. (1942), Act. Med. Scand., 112, 55.

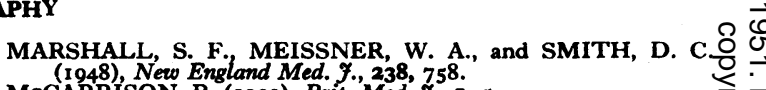

MCCARRISON, R. (1929), Brit. Med. F., I, 5 . Diseases, and Ed.

MEANS, J. H. (1948), 'The Thyroid and its Diseases,' 2nd Ed., MCSWAIN, B., and MOORE, S. W. (1943), Surg., Gyn. and

MCCLINTOC. 76, 562 . C. and WRIGHT, A. W. (1937), Ann. Surg., 106, 11 .

MERRINGTON, W. R. (1948), Brit. F. Surg., 35, 523.

OLDFIELD, M. C. (1948), Brit. F. Surg., 35, 325 .

PATERSON, H., and STARKEY, G. (1948), Ann. Surg., $128,756$.

PARMLEY, C. G., and HELLWIG, C. A. (1946), Arch. Surg., 53, 190.

PEDIGO, G. W., and ABRAMSON, W. (1947), Ann. Int. Med.,

PERMAN, E., and WAHLGREN, F. (1927), Act. Chir. Scand.

POER, D..H., DAVISON, T. C., and BISHOP, E. C. (1936),

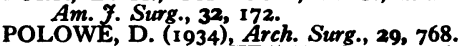

RAWSON, R. W., STERNE, G.' D., and AUB, J. C. (1941), Tr. Am. Ass. Study Goitre, p. I59,

REIST, A. (1922), Zeitsch. f. Path., 28, 141.

RENTÓN, J. M., CHARTERIS, A. A., and HEGGIE, J. F.

RIEDEL, B. M. C. L. (1896), Verhand. d. Deutsch. Gesellsch. $f$. Chir. 25, ror.

ROULET, R. (1931), Virch. Arch. 280, 640.

SCHILLING, G. A. (1945), Surg., Gyn. and Obstet., 81, 533.

SHAW, A. F. B., and SMITH, R.P. (1925), Brit. F.' Surg., 13, 93.

SHEEHAN, H. L., and SUMMERS, V. K. (1949), Quart. $\mathcal{F} . M e d$. .,

I8, 319.9 , M. (1913), Virch. Arch., 211, 73.

SIMMONDS, M. (1923), Virch. Arch., 246, 140

SINAIKO, E. S. LAWRENCE, C. H., and ZITMAN, I. (1948). F. Int. Coll. Surg., 11, 62.

TAYLOR, SELWYN' (1951), Personal communication.

VAUX, D. M. (1938), B. Ұ. Path. Bact., 46, 441.

VINES, H. W. C., Green's Manual of Pathology, 16 th Ed., p. 832, Bailliere, Tindall \& Cox, London.

WEGELIN, quoted by HERTZ, 1943

WILLIAMSON, G. S., and PEAKSE, I. H. (1929), Brit. Med. Y..

WHI'TÉSELL, F. B., and BLACK, B. M. (1949), Э. Clin. Endocr., WOM้A ${ }^{1202 .}$. N. A. (1944), Surgery, 16, 770. 


\section{Summary}

I. The main electrocardiographic changes found with hyperkalaemia are tall pointed $\mathrm{T}$ waves; characteristic ST segment depression; intraauricular, intra-ventricular and auriculo-ventricular block and prolonged QT interval. In the early stages the latter may be shortened. In advanced potassium intoxication, various forms of ventricu- . lar arrhythmia may supervene.

2. In hypokalaemia the QT is prolonged, prominent $\mathrm{U}$ waves appear, ST segments are depressed and $\mathrm{T}$ waves are low or inverted.

3. Hypercalcaemia causes auricular-ventricular block, shortening of the QT interval and low $\mathrm{T}$ waves. Bradycardia and sinus arrhythmia may occur.
4. The main feature of hypocalcaemia is lengthening of the QT interval.

5. Abnormal serum concentrations of potassium and calcium may be present at the same time and both may influence the electrocardiogram.

6. The electrocardiogram is valuable in the diagnosis and management of electrolyte imbalance since it represents the summation of effects of ionic disturbances affecting the heart.

Certain observations mentioned above were made possible by a grant from the National Heart Institute, United States Public Health Service (Grant No. H-446).

Walter Somerville, M.D., M.R.C.P., Cardiac Department, The Middlesex Hospital.

\section{BIBLIOGRAPHY}

BARKER, P. S., JOHNSTONE, F. D., and WILSON, F. N. (1937), Amer. Heart F., 14, 82.

CLARKE, N. E. (194I), Ibid., 22, 376.

GASS, H., CHERKASKY, M., and SAVITSKY, N. (1948), Medicine, 27, 105.

GAMBLE, J. L. (1942), 'Chemical Anatomy, Physiology and Pathology of Extracellular Fluid,' Boston.

HOFF, H. E., SMITH, P. K., and WINKLER, A. W. (1939), Amer. F. Physiol., 125, 162.

KELLOGG, F., and KERR, W. J. (1936), Amer. Heart F., 12, 346.

LEVINE, H. D., MERRILL, J. P., and SOMERVILLE, W. (195I), Circulation, in press.

MARTIN, H. E.,, and WERTMAN, M. (1947), Amer. Heart F., 34, 646.

MERRILL, J. P., LEVINE, H. D., SOMERVILLE,
W., and SMITH, S., 3rd (1950), Ann. intern. Med., 33, 797.

NADLER, C. S., BELLET, S., and LANNING, M. (1948), Amer. F. Med., 5, 838.

SHARPEY-SCHAFER, E. P. (1943), Brit. Heart $\mathcal{F}$., $5,80$.

SHERRY, S., EICHNA, L. W., and EARLE, D. P. JuN. (1948), F. Clin. Invest., 27, 556.

SOMERVILLE, W., LEVINE, H. D., and THORN, G. W. (195I), Medicine, 30, 43.

WALLACE, W. M., and MOLL, F. C. (1949), Pediatrics, 4, 287.

WINKLER, A. W., HOFF, H. E., and SMITH, P. K. (1938), Amer. F. Physiol., 124, 478.

WINKLER, A. W., HOFF, H. E., and SMITH, P. K. (1939), Ibid., I27, 430 .

\section{ERRATUM}

The Editors regret that in our April number the illustrations to Mr. D. R. K. Reid's article on Hashimoto's Disease appear in wrong order. Figure I should be figure 4, figure 2 should be figure I and figure 4 , figure 2. 